\title{
Is migration a unique field of study in social sciences? A response to Levy, Pisarevskaya, and Scholten
}

\author{
James F. Hollifield ${ }^{1,2}$
}

Correspondence: jhollifi@smu.edu ${ }^{1}$ Tower Center, SMU, Dallas, TX, USA

${ }^{2}$ Global Fellow, Wilson Center, Washington, DC, USA

\begin{abstract}
The emergence of a new research field or area of study in the social sciences always is fraught with controversy, fits and starts, theoretical, methodological, and even epistemological debates. Migration studies is no different, but some things are relatively unique about this 'new' field of study, while others are more conventional. The article on the 'rise of migration studies' by the CrossMigration team, Levy et al. (Comparative Migration Studies, 8 forthcoming), "Between Fragmentation and Institutionalization" under consideration here captures some of the controversies in migration studies, and poses some interesting questions about the direction of the field. Building on the 'bibliometric analysis' of journal articles by the cross-migration group, I ask what is unique about migration studies and what is conventional?
\end{abstract}

Keywords: Migration, Sociology, Assimilation, Economics, Politics, Disciplines, Anthropology, International

The emergence of a new research field or area of study in the social sciences always is fraught with controversy, fits and starts, theoretical, methodological, and even epistemological debates. Migration studies is no different, but some things are relatively unique about this 'new' field of study, while others are more conventional. The article on the 'rise of migration studies' by the 'cross-migration' team, (Levy et al. 2020), "Between Fragmentation and Institutionalization" under consideration here captures some of the controversies in migration studies, and poses some interesting questions about the direction of the field. Building on the 'bibliometric analysis' of journal articles by the cross-migration group, I ask what is unique about migration studies and what is conventional?

Let me start with the conventional, portrayed well in the analysis by the crossmigration team. Migration has been a topic of inquiry in the social sciences for decades, and in the field of sociology, the focus on migration studies dates from the late nineteenth century. The fact that sociology, particularly as practiced in the United States, was the first discipline to make the study of migration a central feature of inquiry is not a coincidence. As Levy et al. 2020 point out, the beginning of migration studies dates from the works of Ravenstein (1885), and early twentieth-century

(c) The Author(s). 2020 Open Access This article is licensed under a Creative Commons Attribution 4.0 International License, which permits use, sharing, adaptation, distribution and reproduction in any medium or format, as long as you give appropriate credit to the original author(s) and the source, provide a link to the Creative Commons licence, and indicate if changes were made. The images or other third party material in this article are included in the article's Creative Commons licence, unless indicated otherwise in a credit line to the material. If material is not included in the article's Creative Commons licence and your intended use is not permitted by statutory regulation or exceeds the permitted use, you will need to obtain permission directly from the copyright holder. To view a copy of this licence, visit http://creativecommons.org/licenses/by/4.0/. 
sociology (Thomas and Znaniecki 1918). In this period, the dominant paradigms in migration theory were the assimilation model, associated with Robert Park (1930) and the "Chicago School (see also Gordon 1964)." The assimilation model, which predicted a single outcome, eventually gave way to new models predicting a range of outcomes, as reflected in Portes and Rumbaut's (1990) now classic study of immigrant incorporation in the United States. They predicted outcomes for different groups according to contexts of reception that vary with reference to (1) policy that accepts or actively supports immigrants; (2) labor market reception that is neutral, positive, or discriminatory; and (3) ethnic communities that are either nonexistent, working class, or entrepreneurial/ professional. Also of interest to the 'Portes School' are issues of human and social capital. In the late twentieth century, sociologists emphasized the role of social capital (the social networks and social relationships of immigrants, Bourdieu 1977; Portes and Zhou 1993) in facilitating incorporation while economists placed greater emphasis on human capital criteria (schooling, professional qualifications, language proficiency, and the like, Chiswick 1978) in facilitating incorporation-all quite conventional social science.

It is therefore not surprising when Levy et al. 2020 look at the emergence of co-citation networks during this period (1980s and '90s, Figures 7-9) that the field of migration studies tended to cluster around ethnic and race relations, assimilation and acculturation, and a 'Wisconsin or Michigan School,' with Portes (a Wisconsin PhD) at the heart of this approach. This 'school' is heavily inductive, positivist, behavioural, and 'data driven,' making it quite conventional from the standpoint of philosophy of social science. Social demographers (like Douglas Massey, also with his own 'node' in the cross-migration citation networks) have been instrumental in defining the field of migration studies, focusing on population dynamics, the pattern and direction of migration flows, and the characteristics of migrants (age, gender, occupation, education, and so on). Social demographers seek to understand how and why people migrate, what happens to migrants, especially in the receiving society where they are likely to have a major impact on the population, and how difficult it is for migrants to be 'absorbed' into the host society. Demography plays a major role in migration studies because of the imbalances between populations, leading to push factors in overpopulated societies and pull factors in underpopulated societies, hence the proliferation of push-pull models in migration studies. In addition to individuals, social demographers develop theories of household behavior-a primary unit of analysis-and they delve into economic theory, looking at the structure and functioning of labor markets (hence economic sociology emerges in the cross-migration citation networks) to understand how these affect the propensity for people to move. Demographers wrestle with the same concepts as sociologists (and later anthropologists), such as ethnicity and race, and they theorize about intermarriage rates, social capital, and civil society and help us to understand the effects of immigration on receiving societies. They illustrate how and why some immigrant groups adapt and integrate better than others, echoing the findings of sociologists like Alejandro Portes, Roger Waldinger, Richard Alba, and others, and giving us what David Fitzgerald (2015) has called an 'ethnic Olympics.'

Economists still with a laser-like focus on the United States and sticking with conventional social science have been equally influential in the development of the field of migration studies, relying on rationalist and utilitarian theories of human behavior. They frame their research questions in terms of scarcity, cost-benefit, and rational choice. Like sociologists, they are interested in why some people move while others do not, 
paying close attention to selectivity to determine what migration means for the sending and receiving societies (Chiswick 2008). The macroeconomic perspective explores what immigrants add to the economy of the receiving society (in terms of wealth, income, skills, etc.), what emigrants take away from the economy of the sending society (in terms of capital, human and otherwise), what they send back in remittances, and what is the net gain. From a microeconomic perspective, economists view migrants as utility maximizers who assess opportunity in cost-benefit terms and act accordingly (Martin 2015). These two perspectives (macro and micro) have generated a range of questions and debates within economics about winners and losers in labor markets where migrants are present, about the impact of immigration on public finance, about entrepreneurship and innovation, and about the social mobility of immigrants-questions that economists share with sociologists. Certainly these two disciplines have created "a common... language... a rather unified and stable conceptual and theoretical foundation," with the "standardization of norms and practices" for the field (Levy et al. 2020, pp. 2-3).

Economists often are called upon (by those who formulate policy) to assess the fiscal and human capital costs and benefits of immigration in precisely these evaluative terms. Costbenefit analysis therefore shapes many of the theoretical debates in economics (Chiswick 1978; Borjas 1985), not to mention broader debates about the effects of immigration policy on the macro-economy (again Martin 2015). To take two prominent examples, Barry Chiswick (1978), in contrast to George Borjas $(1985,1987)$, argues that higher levels of inequality in the country of origin do not necessarily lead to negative selectivity of immigrants, but rather to less favorable positive selectivity. In effect, according to Chiswick (2008), even though immigrants may come from very poor countries, they still are favorably selected compared to those who stay behind, and are likely to add to the human capital stock of the receiving country and to assimilate quickly. In this framework, immigrants' earnings are likely to increase at a higher rate than the earnings of natives. Hence, economists and sociologists are focused on many of the same questions concerning the incorporation or assimilation of immigrants, even though their theories and methods are quite different. Economists and demographers have also explored the educational, welfare, and social security costs of immigration. Americans in particular are concerned about the costs and benefits of immigration and want to harness the social sciences, especially economics, to shape and inform policy debates (Martin 2015; National Academy of Sciences 2017). European scholars (Zimmermann and Kahanec 2009) also are concerned about the macroeconomic and labor market impacts of immigration, but most European governments (and scholars) are preoccupied with perceived crises of integration and with the effects of immigration on the welfare state (Favell 1998; Bommes and Geddes 2000; Brochmann 2014).

Finally and in sticking with conventional approaches to the study of migration, one could argue that the growth of work on the second generation, particularly within the discipline of sociology, is a result of the rejection of the assumptions of earlier assimilation theory (Perlmann and Waldinger 1997; Portes and Zhou 1993). Some scholars (see again George Borjas 1985) have argued that given postindustrial economies and the diversity of places of origin of today's immigrant populations, the path to upward mobility (and hence incorporation) will be much less favorable for the second generation than it was for the second generation of the past. Clearly, this is a topic of intense debate and another area of research and theory building, dominated by an exclusive focus on US immigration, with sparse attention to other immigrant-receiving societies (cf. 
Alba and Foner 2015). Migration studies has suffered from a lack of comparativehistorical perspective (cf. Lucassen and Lucassen 1997) and it was heavily 'siloed' with little cross-disciplinary work, leading to more fragmentation and frequent 'reinvention of the wheel' (Levy et al. 2020, p. 16 and Brettell and Hollifield 2015).

Perhaps the controversial nature of the debate about the second generation, and the power of the transnational model, have placed the assimilation model back on the table. Alba and Nee (2003, see also Fitzgerald 2015), for example, suggest that assimilation theory should be resurrected without the prescriptive baggage formulated by the dominant majority that calls for immigrants to become like everyone else. They argue that assimilation still exists as a spontaneous process in intergroup relations. Certainly, the preoccupation in several disciplines with the transnational model (which has its own cluster in Levy et al. 2020) may be a reflection of research that focuses largely on the first generation and that lacks a historical perspective. Herbert Gans (1997) suggested that rejection of straight-line assimilation may be premature, given not only the different generations of immigrants studied by those who originally formulated the theory and by those carrying out contemporary research, but also differences in the background (outsiders versus insiders) of researchers themselves.

From this cryptic review of the history, we can see one unique feature of the field of migration studies. The experience of immigration in the settler/colonial societies, especially the United States but also Canada, Australia, and even South Africa and New Zealand (the Dominions), has dominated research on migration in the social sciences, making the field exceptionally western, Anglo-Saxon, and ethnocentric (Brettell and Hollifield 2015; Hollifield and Foley: Understanding global migration, forthcoming). Again, this is quite clear in the co-citation clusters and 'epistemic communities' depicted in Figs. 7-9 of the article by the cross-migration group. The research agendas of American sociologists and economists are heavily focused on migrant agency and experience, and these agendas were exported first to Canada and Australia, then to the United Kingdom, making the field look even more ethnocentric, as it was dominated by English-language scholarship (see Fig. 6 on 'cross-national co-authorships'). Eventually the dominant paradigms of ethnic and race relations, acculturation, assimilation, ethnic entrepreneurship, embedded in a broad 'world systems' framework (Wallerstein 1976) would be exported to continental Europe having a big impact on the development of migration studies in The Netherlands, Germany, Scandinavia, and somewhat later in France and southern Europe (see Fig. 6 in Levy et al. 2020). As Europe made the transition from a continent of emigration (in the nineteenth and early twentieth centuries) to a land of immigration in the post-World War II era (Thränhardt 1996), it is not surprising that European scholars of migration would turn to American and British theories to frame their research questions (see the introduction in Brettell and Hollifield 2015). However, the historical context of migration in Europe is quite different from that of the settler societies. Many of the new immigration countries in Europe have struggled with the legacies of imperialism, and post-colonialism, making the US assimilation or acculturation paradigms especially inappropriate. This tension is especially evident in countries with a long imperial history, like Britain and France, but also The Netherlands, Belgium, and Italy and Portugal (Hollifield et al. 2014; Hollifield and Foley: Understanding global migration (forthcoming)). In Northern Europe the preoccupation with the social contract and the viability of the welfare state have tended to dominate migration studies (Brochmann 2014). 
Another unique feature of migration studies - as opposed to other fields of study in the social sciences-is the extent to which it is ethnocentric, driven by specific historical and cultural contexts. The experience of the settler societies (the U.S. and the Dominions but also Latin America, see Hollifield and Foley: Understanding global migration (forthcoming)) is unique, and the weight of imperialism is evident in both the sending and receiving societies of Western Europe and almost every other region of the globe touched by conquest and colonization. Little attention has been paid to the impact of European migrations on indigenous peoples in the Americas, Africa, and Australia, for example. These lacunae make history and anthropology especially important in the study of migration, to move us away from a narrow focus on migrant agency in the dominant paradigm of economic sociology and demography, to take account of larger historical, structural (institutional), and transnational forces at work in the movement of populations. For this reason, a more critical approach to migration is needed, to bring non-western perspectives to bear in understanding migration, and to gain a greater appreciation of the power dynamics between peoples, regions, and states (Hollifield and Foley: Understanding global migration (forthcoming); cf. Massey 1999). It will take much more than cross-country collaborations (Levy et al. 2020, p. 4) to overcome the western bias in migration studies. In this regard, the 'cultural turn' in migration studies (Levy et al. 2020, p. 5) should help attenuate the western bias.

Returning to sociology — the first discipline in migration studies-as FitzGerald (2015) emphasizes, the central questions are why does migration occur and who migratesthat is, issues of selectivity? How is migration sustained over time (through networks)? What happens once these populations settle in the host society and begin to take part in a multigenerational competition for resources and status, often defined in ethnic terms? Sociologists share a common theoretical framework with anthropologists and there is a good deal of cross-fertilization between these disciplines. Both are grounded in the classic works of social theory (Marx, Durkheim, and Weber), and each tends to emphasize social relations as central to understanding the processes of migration and immigrant incorporation.

However, sociologists have worked primarily in the receiving society with some notable exceptions (see the works of Massey and Durand 2004; Fitzgerald 2008 on Mexico; and de Haas 2010, for example), while anthropologists have often worked in the countries of origin, destination, or both. The difference is a result of the historical origins of these two disciplines-sociology is grounded in the study of Western institutions and society, whereas anthropology began with the study of "the other." Anthropology "came later" to the study of migration and immigration, but in sociology it has been a topic of longstanding interest. Sociological questions are generally also outcomes questions. Even though sociologists are interested in the causes of emigration (again see Fitzgerald 2008; de Haas 2010), the discipline places greater emphasis on the process of immigrant incorporation (Portes and Rumbaut 1990; Perlmann and Waldinger 1997; Favell 1998; Bloemraad 2006). Despite the importance of world systems theory (see Fig. 10 in Levy et al. 2020) to both sociology and anthropology, more theorizing in these fields takes place at the micro-level, with a focus on agency, than at the macro-level with a focus on structure.

By contrast, political science and especially international relations (Hollifield 2012), with its focus on the state, policy (process) and institutions, operates comfortably at the macro or systemic level, leaving international relations scholars open to the criticism of 
"methodological nationalism" (Wimmer and Glick-Schiller 2002; Favell 2015). Some political scientists (Hollifield 2004, 2005, 2012; Hollifield and Wong 2015; Zolberg 1981, 2006), sociologists (Waldinger and Fitzgerald 2004 and Joppke 1999; cf. Massey 1999), and jurists (Schuck 1998 and Abraham 2015) argue that migration scholars ignore the nation-state at their peril. Brettell (2015), on the other hand, traces a shift in anthropology from the individual to the household that accompanied the realization that migrants rarely make decisions in a vacuum about whether to leave and where to go and that immigrant earnings and remittances are often pooled into a household economy. Similarly, it is in the distinction between individual decision making, on the one hand, and household or family decision making, on the other, that Massey et al. (1993) locate the difference between neoclassical microeconomic migration theory and the new economics of migration. New economics theorists argue that households send workers abroad "not only to improve income in absolute terms, but also to increase income relative to other households, and, hence, to reduce their relative deprivation compared with some reference group" (Massey et al. 1993, p. 438; see also earlier work by Mincer 1978; Stark 1991). This is an economic theory that, with a different unit of analysis, must take sociological and anthropological questions into consideration (all these scholars are depicted in Levy et al. 2020, Fig. 10).

Another unique feature of migration studies is the difficulty (if not the impossibility) of understanding migration and mobility from a single disciplinary perspective. Despite the dominance of sociology and economics as revealed in Levy et al. (2020), there is a lot of interchange among the disciplines. Historians draw on many of the theories formulated by sociologists (Lucassen and Lucassen 1997; Gabbacia 2015). Demographers are attentive to both sociological and economic theory and, increasingly, to those emerging from political science. Law has close affinity with all the social sciences and with history (Abraham 2015), while political science borrows heavily from economics and history as well as from sociology and law-one could argue that political science is a theoretical vagabond when it comes to the study of migration; and anthropology shares much with history, sociology, and geography (Hollifield and Wong 2015). Although economists also borrow and work with other disciplines-demography, sociology, and history for example-they maintain a focus on their own (quantitative) methodology and (often highly formal) models, especially rational choice. Proponents of rational choice argue that this is an indication of how much more formal modeling is scientific, when compared with other social science disciplines. Detractors would say that economists are so wedded to the rationalist paradigm and to game theory, that they cannot admit that any other approach might be as powerful as a straightforward, interest-based, microeconomic model. An economist might respond with the metaphor of Occam's Razor-simple and parsimonious models are more powerful than the complex models offered by other social science disciplines, and that economics is a more advanced "science," because there is agreement on a unified (rationalist) theory and a common methodology. On the other hand, it is easy to slit one's throat with Occam's Razor!

We can see clear divergences in migration studies in which questions are asked and how they are framed, in units of analysis, and in research methods that are heavily inductive, behavioral, and positivist. Migration studies might best proceed through the development of interdisciplinary research projects on a series of common questions to which scholars in different disciplines and with different regional interests could bring 
distinct insights drawn from their particular epistemological frameworks (See Hollifield and Foley: Understanding global migration (forthcoming)). How, for example, might anthropologists and legal scholars collaborate in the study of so-called cultural defenses that often involve new immigrants and how might the results of this work lead to refinements in theories about migration and change? How might scholars from across a range of disciplines collaborate on a project focused on the financial and health status of undocumented immigrants in several receiving societies with or without government benefits. Bridge building across disciplines also entails identifying a common set of dependent and independent variables, so that it is clear what we are trying to explain and what factors we stress in building models to explain some segment of migrant behavior or the reaction of states and societies to migration.

A topic crying out for interdisciplinary and cross-national research is the impact (political, economic, social, and cultural) of migration in the global south (Massey 1999; de Haas 2010). As noted above, primarily anthropologists and to a lesser extent historians have conducted the most work in the countries of origin, but the questions asked must be expanded through the participation of those in other disciplines, particularly political science (see Sadiq 2009; Betts 2013) and economics (Clemens 2011). Approximately $40 \%$ of global migration is south-south and because of climate change, civil wars, and ethnic conflicts the number of migrants, whether refugees or internally displaced people, is increasing. Migration is increasingly important for human and economic development, and migration is beginning to rival trade and FDI as a driver of interdependence (Hollifield and Foley: Understanding global migration (forthcoming)). The northern (and western) bias in migration studies is essentially a power dynamic, with most theory originating from scholars in the global north, whereas the data are to be found increasingly in the global south. This is clearly reflected in the article by Levy et al. (2020), which depicts the 'internationalization' of the field, co-authorships, and self-reference revolving around scholarly networks in the USA and Western Europe. The 'structure' of the field is driven by the research and policy agenda of scholars in the global north.

Perhaps the biggest (and most unique) challenge in migration studies is to 'bring the state and politics back into' our theoretical and analytical frameworks, which have been heavily society-centric, because of the dominance of sociology and demography in the field (Hollifield and Wong 2015). With the rise of reactive populism (Norris and Inglehart 2019) the politics of migration has taken a radical turn. Nationalism, nativism, and new forms of 'scientific racism' (Thränhardt 1993) are taking us 'back to the future,' and much of the scholarship on migration has been politicized. Politicians of the radical right dismiss decades of research on the economics of migration (immigrants are blamed for taking jobs from natives), immigrant integration (immigrants are blamed for crime, terrorism, insecurity, and an 'unwillingness to assimilate'), and migration and development (refugees and asylum seekers are seen as a burden). Symbolic politics (the push to build a wall along the entire southern border of the U.S., for example) have overwhelmed the realities of migration (Mexico has gone through a demographic transition and net migration from Mexico to the U.S. has been negative since 2007). Clearly, politics and the state matter in migration studies, but how can we 'bring them back in?' Migration policy is one of the principal ways in which states 'discipline' (Foucault 1979) individuals, groups, and populations that fall under their control, and social 
scientists often are caught up in policy agendas that serve dominant interests and the parties in power. It has been pointed out that migration policy is by definition discriminatory, and that states must choose who is allowed to enter, reside, and settle on their territories. For social scientists, this poses a host of ethical and moral dilemmas, and many political theorists have wrestled with the tradeoffs involved in making migration policy (see for example, Carens 2013; Gibney 2004).

Because of the radical turn in the politics of migration, it is more important than ever for scholars to understand the evolution of migration states (Hollifield 2004), how states seek to manage migration for strategic gains, and the role of migration in national and human development in the global north and especially in the global south (Hollifield and Foley: Understanding global migration (forthcoming)). At the same time and given the highly politicized nature of the field, scholars must be ever attentive to the empirical (factand data-based) nature of their work, and they must hew to the Popperian maxim of advancing falsifiable propositions. In this respect, migration studies is quite conventional, even though it has many unique features. None of these dynamics in migration studiesincreasing politicization of the field, the turn away from positive social science, and the rise of nativism and symbolic politics-is captured in the cross-migration analysis of Levy et al. This may be due to the dominance of society-centric paradigms in the field that focus research on individual and group behaviors to the detriment of broader structural and institutional factors that shape human mobility and migration in the longer term.

Author's contributions

The author(s) read and approved the final manuscript.

Competing interests

The author declares that he has no competing interests.

Received: 1 May 2020 Accepted: 1 May 2020

Published online: 02 October 2020

\section{References}

Abraham, D. (2015). Law and migration. In C. B. Brettell, \& J. F. Hollifield (Eds.), Migration theory: talking across disciplines (3rd ed., pp. 289-317). Abingdon: Routledge.

Alba, R., \& Foner, N. (2015). Strangers no more: immigration and the challenges of integration in North America and Western Europe. Princeton: Princeton University Press.

Alba, R., \& Nee, V. (2003). Remaking the American mainstream: assimilation and contemporary immigration. Cambridge, MA: Harvard University Press.

Betts, A. (2013). Survival migration: failed governance and the crisis of displacement. Ithaca, NY: Cornell University Press. Bloemraad, I. (2006). Becoming a citizen: incorporating immigrants and refugees in the United States and Canada. Berkeley: University of California Press.

Bommes, M., \& Geddes, A. (2000). Immigration and welfare: challenging the borders of the welfare state. London: Routledge.

Borjas, G. J. (1985). Assimilation, changes in cohort quality and the earnings of immigrants. Journal of Labor Economics, 3 , $463-489$.

Borjas, G. J. (1987). Self-selection and the earnings of immigrants. American Economic Review, 77, 531-553.

Bourdieu, P. (1977). Outline of a theory of practice, (R. Nice, Trans.). Cambridge: Cambridge University Press.

Brettell, C. B. (2015). Theorizing migration in anthropology: the cultural, social, and phenomenological dimensions of movement. In C. B. Brettell, \& J. F. Hollifield (Eds.), Migration theory: talking across disciplines (3rd ed., pp. 148-197). Abingdon: Routledge.

Brettell, C. B., \& Hollifield, J. F. (2015). Migration theory: talking across disciplines (3rd ed.). Abingdon: Routledge.

Brochmann, G. (2014). Scandinavia. In J. F. Hollifield, P. L. Martin, \& P. M. Orrenius (Eds.), Controlling immigration: a global perspective (pp. 281-301). Stanford, CA: Stanford University Press.

Carens, J. (2013). The ethics of immigration. Oxford: Oxford University Press.

Chiswick, B. R. (1978). The effect of Americanization on the earnings of foreign-born men. Journal of Political Economy, 86 , 897-921.

Chiswick, B. R. (2008). Are immigrants favorably self-selected. In C. B. Brettell, \& J. F. Hollifield (Eds.), Migration theory: talking across disciplines (2nd ed., pp. 63-82). Abingdon: Routledge.

Clemens, M. A. (2011). Economics and emigration: trillion dollar bills on the sidewalk? Journal of Economic Perspectives, 25(3), $83-106$.

De Haas, H. (2010). Migration and development: a theoretical perspective. International Migration Review, 44(1), $227-264$ 
Favell, A. (1998). Philosophies of integration: immigration and the idea of citizenship in France and Britain. New York: St. Martin's Press.

Favell, A. (2015). Migration theory rebooted. In C. B. Brettell, J. F. Hollifield (Eds.), Migration theory: talking across discipline (pp. 318-328). Abingdon: Routledge.

Fitzgerald, D. S. (2008). A nation of emigrants: how Mexico manages migration. Berkeley, CA: University of California Press.

Fitzgerald, D. S. (2015). The sociology of international migration. In C. B. Brettell, \& J. F. Hollifield (Eds.), Migration theory: talking across disciplines (3rd ed., pp. 115-147). Abingdon: Routledge.

Foucault, M. (1979). Discipline and punish. The birth of the prison. New York: Vintage Books.

Gabbacia, D. R. (2015). Time and temporality in migration studies. In C. B. Brettell, J. F. Hollifield (Eds.), Migration theory: talking across discipline (pp. 37-66). Abingdon: Routledge.

Gans, H. J. (1997). Toward a reconciliation of 'assimilation' and 'pluralism': the interplay of acculturation and ethnic retention. International Migration Review, 31, 875-892.

Gibney, M. J. (2004). The ethics and politics of asylum: liberal democracy and the response to refugees. Cambridge: Cambridge University Press.

Gordon, M. (1964). Assimilation in American life: the role of race, religion and national origins. New York: Oxford University Press.

Hollifield, J. F. (2004). The emerging migration state. International Migration Review, 38, 885-912.

Hollifield, J. F. (2005). Sovereignty and migration. In M. J. Gibney, \& R. Hansen (Eds.), Immigration and asylum from 1900 to the present, volume two (pp. 573-576). Santa Barbara: ABC-CLIO.

Hollifield, J. F. (2012). Migration and international relations. In M. R. Rosenblum, \& D. J. Tichenor (Eds.), The Oxford handbook of the politics of international migration (pp. 345-379). Oxford: Oxford University Press.

Hollifield, J. F., Martin, P. L., \& Orrenius, P. M. (Eds.) (2014). Controlling immigration: a global perspective. Stanford, CA: Stanford University Press.

Hollifield, J. F., \& Wong, T. (2015). The politics of international migration: how can 'we bring the state back in? In C. B. Brettell, \& J. F. Hollifield (Eds.), Migration theory: talking across disciplines (3rd ed., pp. 227-288). Abingdon: Routledge.

Joppke, C. (1999). Immigration and the Nation-State: The United States, Germany, and Great Britain. New York: Oxford University Press.

Levy, N., Pisarevskaya, A., \& Scholten, P. (2020). Between fragmentation and institutionalisation: the rise of migration studies as a research field. Comparative Migration Studies, 8. https://doi.org/10.1186/540878-020-00180-7.

Lucassen, J., \& Lucassen, L. (Eds.) (1997). Migration, migration history, history: old paradigms and new perspectives. Bern: Peter Lang.

Martin, P. L. (2015). Economic aspects of migration. In C. B. Brettell, \& J. F. Hollifield (Eds.), Migration theory: talking across disciplines (3rd ed., pp. 90-114). Abingdon: Routledge.

Massey, D. S. (1999). International migration at the dawn of the twenty-first century: the role of the state. Population and Development Review, 25, 303-322.

Massey, D. S., Arango, J., Hugo, G., Kovaouci, A., Pellegrino, A., \& Edward Taylor, J. (1993). Theories of international migration: a review and appraisal. Population and Development Review, 19, 431-466.

Massey, D. S., \& Durand, J. (2004). Crossing the border: research from the Mexican migration project. New York: Russell Sage Foundation.

Mincer, J. (1978). Family migration decisions. Journal of Political Economy, 86, 749-773.

National Academy of Sciences (2017). The economic and fiscal consequences of immigration. Washington, DC: National Academy of Sciences.

Norris, P., \& Inglehart, R. (2019). Cultural backlash? Trump, Brexit, and authoritarian populism. Cambridge: Cambridge University Press.

Park, R. E. (1930). Assimilation, social. In E. Seligman, \& A. Johnson (Eds.), Encyclopedia of the social sciences (p. 281). New York: Macmillan.

Perlmann, J., \& Waldinger, R. (1997). Second generation decline? Children of immigrants, past and present-a reconsideration. International Migration Review, 31, 893-922.

Portes, A., \& Rumbaut, R. G. (1990). Immigrant America: a portrait. Berkeley and Los Angeles: University of California Press.

Portes, A., \& Zhou, M. (1993). The new second generation: segmented assimilation and its variants among Post-1965 immigrant youth. The Annals of the American Academy of Political and Social Science, 530, 74-96.

Ravenstein, E. (1885). The laws of migration. Journal of the Statistical Society of London, 48(2), 167-235.

Sadiq, K. (2009). Paper citizens: how illegal immigrants acquire citizenship in developing countries. New York: Oxford University Press.

Schuck, P. H. (1998). Citizens, strangers, and in-betweens: essays on immigration and citizenship. Boulder, CO: Westview Press.

Stark, O. (1991). The migration of labor. Cambridge: Basil Blackwell.

Thomas, W., \& Znaniecki, F. (1918). The polish peasant in Europe and America. Boston: Badger.

Thränhardt, D. (1993). Die Ursprünge von Rassismus und Fremdenfeinlichkeit in der Konkurrenzdemokratie [The Origins of Racism and Xenophobia in Competitive Democracy]. Leviathan, 21(3), 336-357.

Thränhardt, D. (1996). Europe: a new immigration continent. Münster: Lit verlag.

Waldinger, R., \& Fitzgerald, D. (2004). Transnationalism in question. American Journal of Sociology, 109(5), 1177-1195.

Wallerstein, I. (1976). The modern world system. New York, NY: Academic Press.

Wimmer, A., \& Glick Schiller, N. (2002). Methodological nationalism and beyond: nation-state building, migration, and the social sciences. Global Networks, 2(4), 301-334.

Zimmermann, K., \& Kahanec, M. (2009). EU labor markets after post-enlargement migration. Berlin: Springer-Verlag.

Zolberg, A. R. (1981). International migration in political perspective. In M. M. Kritz, C. B. Keely, \& S. M. Tomasi (Eds.), Global trends in migration: theory and research in international population movements. New York: Center for Migration Studies.

Zolberg, A. R. (2006). A nation by design: immigration policy in the fashioning of America. New York, Cambridge Russell Sage and Harvard University Press.

\section{Publisher's Note}

Springer Nature remains neutral with regard to jurisdictional claims in published maps and institutional affiliations. 